\title{
Evaluating The Performance of Flood Prevention Programs in Bandung Regency: Using Logic Model
}

\author{
Rosy Riani Kusuma ${ }^{1}$, Ida Widianingsih ${ }^{2}$, Sintaningrum ${ }^{3}$, Rita Myrna ${ }^{4}$ \\ ${ }^{1}$ Faculty of Social and Political Sciences, Universitas Padjadjaran (email: rosy18002@mail.unpad.ac.id), ${ }^{2}$ Faculty of \\ Social and Political Sciences, Universitas Padjadjaran, ${ }^{3}$ Faculty of Social and Political Sciences, Universitas \\ Padjadjaran, ${ }^{4}$ Faculty of Social and Political Sciences, Universitas Padjadjaran
}

\begin{abstract}
In this era of, the public gives more attention to the achievements of government performance, including the regional government. One of the problems is the repeated floods in the Citarum Watershed. However, because disaster events can occur at any time with different locations, there are difficulties for regional leaders and their staff to measure and evaluate the quality and performance of the disaster management programs that they have carried out, especially in situations of emergency response. The large flood of Upper Citarum has damaged buildings and disrupted infrastructure functions due to 12,654 buildings submerged and damage such as potholes and foundation damage many local roads and the closure of a number of schools and other social buildings. Evaluation of the performance of disaster management programs is needed in order to know program performance to develop and to increase capacity and services performed. This study will expose what has been done by the Bandung District Government to overcome the problem of flooding in the Upper Citarum watershed during the last 3 years and evaluate the performance of the Bandung Regency Government to tackle the problem of floods that have recurred in that area using Logic Model.
\end{abstract}

Keywords:

flood management; logic model; program evaluation

\section{Introduction}

In this era of transparency, the public gives more attention to the achievements of government performance including local government performance in disaster management program. According to Lehtonen (2005) there is an increasing interest in the use of evaluation of government policies relating to the environment due to the pressure on the public sector to increase accountability and the relationship between environmental policies and sustainable development. Previous studies show there is a political problem if the government is less successful in handling disasters. For example (Akbar \& Aldrich, 2015) concluded that flooding in Pakistan has a negative influence on people's perceptions of leadership and studies (Nicholls \& Picou, 2013) revealed about the negative effect of 
Hurricane Katrina on the level of community trust in the government and the level of community satisfaction. However, (Albrecht, 2017) concludes that there is no relationship between disaster management by the government and the level of trust and satisfaction with the government.

Interestingly, more than four decades ago (Poland, 1974) had questioned why public administration paid less attention to the role of evaluation as well (Stame, 2006) which stated that there was pressure on the culture of public administration to undermine the role of evaluation. This pressure has made the need for program evaluation in the United States particularly unclear coupled with the limitations of evaluator and budget capabilities (Hatry, 2013). However, studies show the benefits of performing local government performance evaluations, for example (Busson, 1983) concludes that performance evaluation is one of the government's ways to develop programs and improve performance and also (Kariuki \& Reddy, 2017) shows the importance of monitoring and evaluation carried out by local governments and the need for political and regional leadership support for the monitoring and evaluation.

Twigg ( 2007) states that monitoring and evaluation methods for disaster management receive less attention and less than monitoring and evaluation of matters relating to development. In his notes, he also emphasized that in the evaluation process there is a need for balancing portion between external and internal evaluators and the determination of participants. However, (Hansson, Danielson, \& Ekenberg, 2008) concluded that a standardized method for evaluating flood management strategies is needed so that decisions can take effective and efficient disaster management measures. In addition, some studies offer a framework for evaluating local government performance in managing disasters. In the past two decades a number of researchers have sought to determine a framework for evaluating disaster emergency management programs in local government level including (Henstra, 2010), (Dr George Argyrous \& Rahman, 2016), (Birnbaum, Daily, O’Rourke, \& Kushner, 2016), (Larsson, 2008), (Ritchie \& MacDonald, 2010) and (ZantalWiener \& Horwood, 2010).

Disaster management is a set of policies and practices / activities aimed at preventing, managing and reducing the impact caused by disasters (Henstra, 2005) as well as flood management which according to (Burrel et al., 2007) is a set of activities to prevent 
and minimize the possibility the effects of damage caused by flood disasters. Initially, public policy only focused on disaster response because disaster was seen as a natural event (Henstra, 2005) while according to (Sutardi, n.d.) flood management policies in Indonesia initially focused on preventing floods from the view of the development of flood prevention infrastructure. However, (Hapsari \& Zenurianto, 2016) reveal that there are still weaknesses in the stage of flood disaster preparation and prevention in Indonesia. In addition, based on the Report of the Deputy for Facilities and Infrastructure, the Directorate of Irrigation and Irrigation (Deputi Bidang Sarana dan Prasarana, 2010) in research on flood management policies in Indonesia also concluded that community participation as a stakeholder is still lacking with the government's role still dominant, local government policy on disaster management still very limited in prevention activities. It was further concluded that funding for disaster management is still very dependent on the APBN and APBD of the Province and Regency / City, especially in the prevention and rehabilitation stages.

Several attempts have been made to evaluate the performance of local governments in managing disasters with a diversity of multi-dimensional approaches which is related not only to the evaluation of the program but also to projects, strategies and policies. For example, in the USA, a study by (Aerts, Botzen, Emanuel, Lin, \& Moel, 2014) developed a scientific approach to evaluating flood management strategies, by combining storm risk assessment with the level of vulnerability to assets and applying this method to New York City. Another study was done by (Liaw, Tsai, \& Cheng, 2006) that conducted an assessment of flood mitigation in Metro Taipei. In addition (Moe \& Pathranarakul, 2006) developed an integrated approach to effective natural disaster management by taking lessons from disaster management in Thailand who experience tsunami in 2004 and then continued by (Moe, Gehbauer, Senitz, \& Mueller, 2007) who conducted research to the flood disaster management project in Hai Yai City, Thailand using the Balance Score Card (BSC) approach. This study offers a BSC approach to maximize the achievement of the objectives of an activity. Kaushik \& Sharma (2012) also conducted research on flood management in India. An evaluation of flood mitigation has also been carried out in Malaysia by (Khalid \& Shafiai, 2014) to report the effectiveness of the Flood Delivery System.

The performance of local governments in dealing with disasters is also examined by (Gerber \& Robinson, 2009) where they conduct an assessment at the stage of preparation 
and response to disasters. This study concludes that there are limitations to performance measurement and measurement of the outcome of a disaster management policy. (Col, 2007) also conducted a study and comparison of the role of two local governments, the New Orleans government, and the Qinglong County Government in China. While in Indonesia, research (Ulum \& Chaijaroenwatana, 2013) on governance and capacity building of the Bojonegoro Regency Government in overcoming the issue of flooding and Research and (Sari, 2017) on evaluating the effectiveness of the implementation of flood disaster management programs in West Aceh District. Moreover, Study by (Ayumahani \& Ruslanjari, 2018) evaluating the assistance of the Japan International Cooperation Agency (JICA) program to the Regional Disaster Management Agency (BPBD) of Sumbawa Regency in the capacity of flash flood disaster management in Sumbawa Regency, West Nusa Tenggara Province.

However, because disaster events can occur at any time with different locations, there are difficulties for regional leaders and their staff to measure and evaluate the quality and performance of the disaster management programs that they have carried out. One of the flood disasters that are of concern to the community is the recurring flood in three districts of Bandung Regency. In the past ten years, although as an internal auditor, the Government Internal Supervision Apparatus (APIP) in this regard, the Bandung District Inspectorate has the capability to carry out an evaluation program when the APIP capability has reached level 3 in accordance with the BPKP Head of Rules as APIP builder No. 16 of 2015 (BPKP, 2015) on APIP's Enhanced Technical Guidelines, the Government of Bandung Regency has not conducted an Evaluation of the Flood Management Program which is a Regional Development Program in the 2016-2020 and 2010-2015 Medium-Term Development Plan.

Research on evaluating disaster management is an important issue, one of the reason is that there are still failures in disaster management (Zantal-Wiener \& Horwood, 2010). Although some researchers have evaluated the performance of local governments in flood mitigation programs, few have used a public administration approach. Based on the formulation of the problem above, this study aims to evaluate the extent of program performance from the efforts made by the Bandung Regency Government in tackling floods in the Upper Citarum Watershed with the performance of the Flood Prevention Program in 
Bandung District in the last three year. The limitations of the study of the evaluation of disaster management, especially regarding evaluating the performance of local governments on flood prevention programs seen from the point of view of public administration in Indonesia have not been done much, so this research is needed to add empirical evidence on evaluating the performance of a program and is expected to increase the accountability and effectiveness of local governments, especially in terms of flood disaster management.

\section{Methods}

The research method used in this study is a qualitative method of a case study approach. According to (Jonker \& Pennink, 2010) the core of qualitative research is to identify the characteristics and structure of the phenomena and events studied in their natural context. Then, these characteristics are put together to form a mini theory or conceptual model. Qualitative research requires an 'open' attitude to do so, understanding how others experience their situation. The case study approach generally investigates in depth and involves or explores through data collection to describe a phenomenon to gain an understanding of the phenomenon. According to (Yin, 2015), the benefits of evaluating a case study approach include capturing complexity including relevant changes from time to time, being fully present in contextual conditions and being able to explain how cases are usually planned or ongoing initiation.

The purpose of establishing a unit of analysis clearly is to direct how to answer research questions and set limits to avoid checking everything (Yin, 2015). The main unit of analysis is the Bandung Regency Government while the focus of the research is the Disaster Management Program in Bandung Regency. In this study, the Flood Mitigation Program in Bandung Regency is in 2 (two) Regional Apparatus Organizations (OPD), namely the Public Works Agency and the Regional Disaster Management Agency (BPBD), while in the case of finance it is in the Revenue and Finance Office, the planning function is the Agency Regional Planning and supervisory function at Bandung Regency Inspectorate. This study also uses triangulation where primary data in the form of questionnaires and interviews and secondary data in the form of literature studies and other documents are examined to obtain complete data and support overall analysis. The study covers interpretation and 
interpretation of data, conducting field research, setting research focus, constructing phenomena and making reports systematically.

This study uses data collection techniques such as:

1. Literature study to collect research-related literature

2. Interviews with key actors (informants) for data collection

3. Reviewing documents related to regulations on disaster management especially the Flood Management Program in Bandung District, strategic planning documents and annual performance plans, performance agreements, performance accountability reports for the last 10 years starting from the district level up to the OPD level, activity reports related to the Program Flood Management, financial accountability reports, district-level risk registers and OPD levels.

This study uses the Disaster Logic Model (DLM). According to (Birnbaum et al., 2016) although there have been many studies conducted to evaluate disaster management programs, there are limitations in evaluating several intervention activities related to disaster because it is difficult to do randomize control trials (RCT). DLM emphasized the importance of research related to interventions on disaster management in order to get the development of standards and best practices and accountability of a program. Birnbaum et al (2016) offer a DLM where the term logic model was first used by Wholey in 1979. This research is motivated by the absence of a logic model that can be applied appropriately in evaluating interventions carried out before, during and after a disaster or other emergencies. The DLM is inspired by the University of Wisconsin Logic Model which has been used to evaluate educational programs, as shown in the example in Figure 4. Based on (Birnbaum et al., 2016), the differences between ordinary logic models and DLM are:

- DLM links the goals and objectives of an intervention with identified needs

- DLM links the effects of interventions with goals and objectives

- DLM links results to the objectives of the intervention

- DLM links impacts to the overall objectives of an intervention 
Figure 1.

Disaster Logic Model

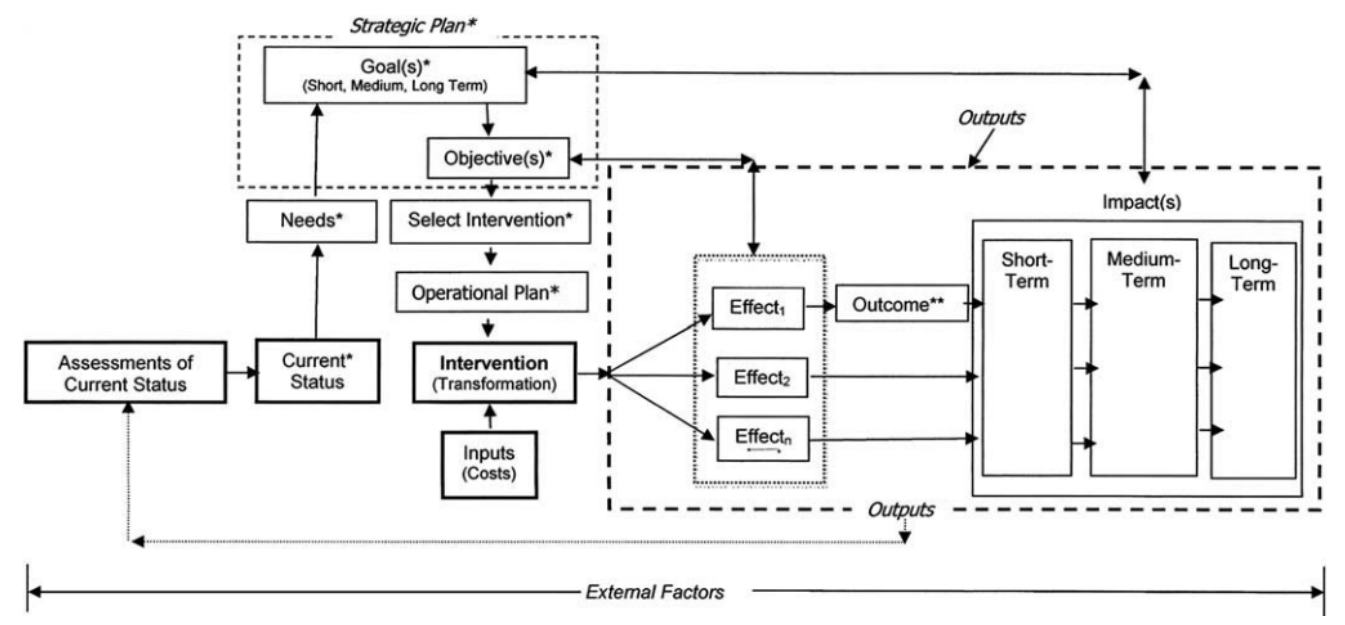

Source: (Birnbaum et al., 2016)

\section{Results and Discussion}

In 2011, Bandung Regency was ranked fourth in the Indonesian Disaster Hazard Index (Lilik, Yunus, Muhammd, \& Narwawi, 2011) as a district in Indonesia with high category of disaster-prone classes and 12th for the Flood Prone Index with high categories. Bandung Regency based on the Report (BNPB, 2016) has a risk of flooding with 419,647 fatalities, physical risk valued at Rp1,697,137,000,000.00 in the high category and economic risk worth Rp538,200,000,000.00. This problem has occurred since 1931 so it requires a thorough and serious treatment (Hidayat, Murtilaksono, Wahjunie, \& Panuju, 2013). Some of the sub-districts affected by the flood are located in the Upper Citarum River Basin (DAS) where the Citarum watershed in 2013 was the third polluted region in the world based on reports from Green Cross Switzerland and Blacksmith (Blacksmith Institute, 2013). In addition, in 2016 there was a drastic increase in flood events, the number of people affected by floods and a surge in refugees as a result of the disaster flooding as shown in the table 1 below, however flooding due to annual overflow of the Citarum River still occurs in the Baleendah, Bojongsoang and Dayeuhkolot areas and inundates more than 1,500 houses in 2019 (Liputan 6, 2019). 
Table 1.

Number of Events and Flood Victims in Bandung Regency

(For The Year 2012 - 2017)

\begin{tabular}{|r|r|r|r|}
\hline Year & \multicolumn{1}{|c|}{$\begin{array}{c}\text { Flood } \\
\text { Incidents }\end{array}$} & \multicolumn{1}{c|}{ Victim } & \multicolumn{1}{c|}{ Evacuee } \\
\hline 2015 & 12 & 20.155 & 316 \\
\hline 2016 & 55 & 124.413 & 5.694 \\
\hline 2017 & 19 & 54 & 16 \\
\hline
\end{tabular}

Source: BPBD Bandung Regency

The Performance of Bandung Regency Government indicators for the 2014 Flood Control Program were not presented in the Bandung District Government Performance Accountability Report (P. K. Bandung, 2015) while in 2016 the Bandung Regency Government performance indicators for the Flood Control Program were programs to achieve the target: "increasing efforts to handle flooded communities "with a budget realization of Rp. 9,221,532,760.00. Even though it has reached $92.43 \%$ of the realization target previously set but based on the 2016 Performance Accountability Report (P. K. Bandung, 2017b) the efficiency value of achieving the target performance is only $54.34 \%$. It can be stated that the process of achieving performance on this target for 2016 carried out through the Flood Control Program has not been carried out efficiently. In the 2017 Bandung District Performance Report (Bandung, 2017) it was also stated that the handling of annual flooding was not optimal and the target achievement of targets for "increasing efforts to deal with flooded communities" had not been met.

Regulations and legal basis for managing disaster management in general in Indonesia in general and Bandung Regency in particular uses the applicable provisions as follows:

1. Law Number 24 Year 2007 (P. Indonesia, 2007a) Regarding Disaster Management Disaster Management. The law in principle regulates the stages of a disaster including pre-disaster, during emergency response and post-disaster. This law contains the main provisions in implementing disaster management, including:

a) The implementation of disaster management is the responsibility and authority of the Government, and the Regional Government which is carried out in a planned, integrated, coordinated and comprehensive manner. 
b) Disaster management in the emergency response stage is fully implemented by the National Disaster Management Agency (BNPB) and the Regional Disaster Management Agency (BPBD).

c) The implementation of disaster management is carried out with due regard to the rights of the community including obtaining assistance in meeting basic needs, social protection, education and skills in disaster management, as well as participating in decision making.

d) Disaster management activities carried out by providing broad opportunities to business institutions and international institutions.

e) Supervision of all disaster management activities is carried out by the Government, Regional Governments and the community at each stage of the disaster so that there are no irregularities in the use of disaster management funds.

f) The government is responsible for disaster risk reduction and the integration of disaster risk reduction with the implemented development program.

2. Law Number 26 of 2007 (P. Indonesia, 2007b) Concerning Spatial Planning. Spatial planning based on disaster mitigation is needed in Indonesia considering that Indonesia is in a disaster-prone area. Article 33 states that in the preparation of water resources stewardship considerations, among others, meteorological, climatological, geophysical, and availability of water resources infrastructure, including drainage network systems and flood control.

3. Government Regulation (PP) No. 21 of 2008 (P. Indonesia, 2008b)concerning the Implementation of Disaster Management which regulates the implementation of disaster management including the pre-disaster stage, during the emergency response, and postdisaster. The implementation of disaster management in the pre-disaster phase includes:

a) in a situation where there is no disaster; and

b) in situations of potential disaster.

4. Government Regulation of the Republic of Indonesia Number 22 Year 2008 Regarding Funding and Management of Disaster Relief which includes:

a) sources of funds for disaster management;

b) use of disaster management funds;

c) disaster relief management; and 
d) supervision, reporting and accountability of funding and management of disaster relief.

This Government Regulation also regulates disaster management funds in the postdisaster phase which includes rehabilitation and reconstruction activities (P. Indonesia, 2008a) .

5. Presidential Regulation No. 08 of 2008 concerning the National Disaster Management Agency states that BNPB has the task, among others, to provide guidance and direction to disaster management efforts that include disaster prevention, emergency response management, rehabilitation, and reconstruction fairly and equally and report the implementation of disaster management to the President once a month under normal conditions and at any time in a state of disaster emergency (P. R. Indonesia, 2008).

6. Bandung Regency Regulation No. 11 of 2010 (P. K. Bandung, 2010) concerning the Establishment of the Organization of the Bandung Regency Regional Disaster Management Agency

7. Bandung Regency Regulation Number 2 Year 2013 (P. K. Bandung, 2013b) concerning the Implementation of Disaster Management in Bandung Regency

8. Regent Regulation Number 23 of 2013 (P. K. Bandung, 2013a) concerning the Distribution of Authority, Duties and Functions of Regional Work Units in Disaster Management in Bandung Regency.

This study adapted the Disaster Logic Model from (Birnbaum et al., 2016), by evaluating the performance of the Bandung district development program, the flood prevention program in the strategic planning document 2016 - 2021 with the following evaluation steps:

1. This study conducts an initial assessment and obtain preliminary information on the existing conditions through document evaluation and literature review, as an example of an assessment of the initial conditions before the intervention, infrastructure damage caused by the disaster or the health condition of the affected community.

In the territory of Indonesia, the potential for flooding is caused by approximately ten percent of the 5,590 main rivers in Indonesia (Deputi Bidang Sarana dan Prasarana, 2010). Meanwhile, repeated major floods in the upstream area of the Citarum watershed occurred in 1931, 1984, 1986, 2005, 2007, 2010 and 2012. Specifically in the Bandung 
Regency area, in 2015 there were 12 floods spread in 22 sub-districts in 2016 and 2017 as many as 55 and 19 times respectively (BPBD Kab Bandung, 2017). In general, floodprone areas have three main causes of flooding, namely floods originating from activities carried out by humans, floods that occur due to natural events and the third cause is floods caused by environmental degradation. Meanwhile, upstream areas that are bare, excess water use and resulting in land surface declines and poor habits of the people who live around rivers are some factors that contribute to flooding in the Citarum watershed according to (Arief, 2013). In addition, changes in land use in the upstream Citarum watershed from forestry to agriculture also triggered flooding in the South Bandung area.

Flooding in the Upper Citarum has caused damage to the building and disrupted the function of infrastructure due to 12,654 buildings submerged and caused damage such as potholes and damaged foundation on many shoulders on local roads and the closure of a number of schools and other social buildings. Coupled with the frequency of flood disasters in the Bandung Regency region is classified as high where in the period October 2013 to September 2014 (within one year) floods occurred 128 times, and the still vast area of potential flooding where in 2014 reached an area of 14,91790 Ha (BAPPEDA Kabupaten Bandung, 2015).

Muhamad, Sekarningrum, \& Yusar (2017) research on the dimensions of social capital in three districts in Bandung Regency shows that after the flood there was a decrease in the level of trust in the government due to suspicion of manipulation and delay in the provision of aid. While the level of trust between communities is still quite strong but there is a weakening. Weakening also occurs in the norm dimension because people are starting to depend on government assistance. However, a positive thing for the network dimension is the formation of local communities in flood management. Meanwhile according to (Istiani, 2016), the health condition of the people who experienced flooding in Baleendah suffered from itching, fever, flu, water fleas and aches, with the total value of the economic loss of the community during 2015 amounting to Rp1,282,906,077,421.00. 
Figure 2 shows a broad map of flood disaster areas along the Citarum watershed which covers three sub-districts in the Bandung Regency region, namely Bale Endah, Dayeuh Kolot and Bojongsoang Districts.

Figure 2.

Map of the Flood Area in Bandung Regency

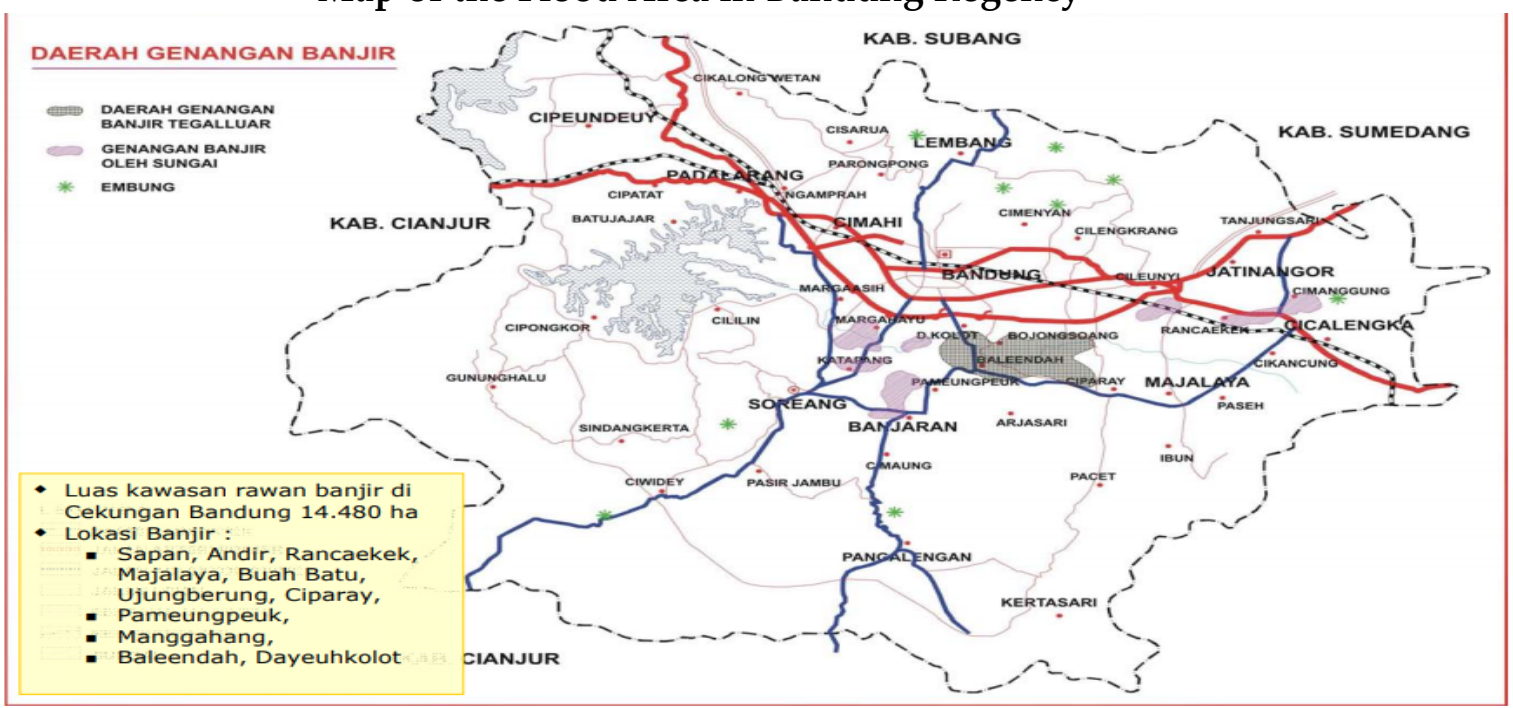

Source: Bandung Regency RPJMD 2005-2010

One of the infrastructures associated with flooding is the drainage network. In 2014, out of $398 \mathrm{~km}$ of drainage in Bandung District, $311 \mathrm{~km}$ of drainage was blocked, in other words only $78.06 \%$ of drainage was in good condition while road infrastructure was in good condition at $54.28 \%$ and the volume of waste handled was $31.23 \%$ (BAPPEDA Bandung Regency, 2015). Another thing related to environmental conditions related to flooding is the percentage of critical land planted in 2014 only reached $49.15 \%$. The report also describes the achievement of the 2010-2015 RPJMD target where the fifth mission is to increase the availability of infrastructure and integrated spatial planning with the goal of increasing the fulfillment of infrastructure and the basic area with performance indicators of the percentage of roads that guarantee vehicles can run safely and comfortably from flooding. has not been shown so that researchers cannot know the achievement of the achievement of these targets. While in 2014, the Flood Control Program at the Bandung Regency Water Resources Office (SDAPE) with a program indicator of regional scale and city scale drainage management with a budget realization of $\mathrm{Rp} 11,218,186,000.00$ had a performance achievement of $232.8 \%$ with financial realization $56.65 \%$. 
2. This study determine what needs assumptions are needed. In this case the needs (needs) are interpreted as the difference between resources or infrastructure needed to achieve certain goals with goods and services needed to meet these requirements.

According to (Deviana, Kridasantausa, \& Suryadi, 2011) some strategies that can be applied to tackle floods in West Bandung regency are divided into short, medium and long term strategies as follows:

\section{A. Short Term Strategy}

- Opening opportunities for maintenance Fund Sharing with private parties for the costs of building and maintaining flood control buildings,

- provide facilities for non-pollutant industries in applying for an extension of business licenses.

- Arranging an Incentive Mechanism for Agricultural Activities in Accordance with Conservation Rules

B. Medium-Term Strategy

- Develop an Environmental Services Mechanism for the Management of Conservation-Based Watersheds

- Restrictions and Control of River Border Space and Flood Plain with vertical Area Development.

- Evaluation of Borderline River according to its Characteristics

C. Long-Term Strategy

- Flood Proofing

- Relocation of Settlements on Existing River Border.

- Disincentive Mechanisms in the Form of Order and Progressive Taxes

- Development of Early Warning Facilities and Emergency Response Mechanisms

- Flood Disasters, in the context of Mitigation and Adaptation Efforts to Climate Change

3. Reviewing the strategic planning. In this case the strategic plan is a document used to communicate with the organization, organizational goals, actions needed to achieve these goals and all other important elements developed during planning activities (Strategic Planning Basic as cited in Birnbaum et al (2016)). The outcome of the 
intervention is the achievement of the level of function stated in the intervention's objectives.

Bandung Regency Government in the past ten years has made efforts to reduce the occurrence of flooding in the region. These efforts are stated in the Regional MediumTerm Development Plan (RPJMD) for 2010 - 2015 which has established the Flood Control Program.In the Bandung Regency RPJMD 2010 - 2015 (Pemerintah Kabupaten Bandung, 2011) there are Flood Control Programs and Emergency Management Programs which are Regional Development Programs. In the RPJMD 2016 - 2021, the third mission of Bandung Regency is "Realizing the development of integrated basic infrastructure with regional spatial planning". Bandung Regency medium planning has considered aspects of disaster. This is based on the condition of Bandung Regency which has several potential disasters, one of which is a flood that disrupts the stability of development.

Based on this, the efforts related to handling disaster aspects in addition to accommodating mitigation efforts, the Bandung Regency government has also made adaptation efforts in the form of infrastructure engineering and public facilities in order to have resilience to disasters. The purpose of the third mission is to improve the quality of basic infrastructure that is sustainable, integrated with spatial planning. There are two targets to carry out these objectives, namely the first target: increasing flood disaster management with inundation area indicators and the second target is increasing disaster management standards with indicators of response time to disasters as seen on Table 2 .

Table 2

The Linkage of Vision, Mission, Goals and Objectives of Bandung Regency 2016-2021

\begin{tabular}{|l|l|l|}
\hline \multicolumn{3}{|c|}{$\begin{array}{l}\text { Vision: } \\
\text { "Strengthening the Bandung Regency which is Advanced, Independent and Competitive, through } \\
\text { Good Governance and Synergy in Rural Development, Religious, Cultural and Environmental- } \\
\text { Based Development" }\end{array}$} \\
\hline \multicolumn{1}{|c|}{ Goals } & \multicolumn{1}{c|}{ Objectives } \\
\hline \multicolumn{1}{|c|}{ Mission } & \multicolumn{1}{|c|}{ 1. Increased flood control } \\
"Realizing the & $\begin{array}{l}\text { Improving quality of basic } \\
\text { development of } \\
\text { basic infrastructure } \\
\text { integrated with } \\
\text { spatial planning" }\end{array}$ & $\begin{array}{l}\text { sustainable, that is } \\
\text { integrated with } \\
\text { governance planning }\end{array}$ \\
\hline
\end{tabular}

Sumber: RPJMD Bandung Regency 2016 -2021 
For RPJMD 2016 - 2021, the Regional Development Program related to flooding is the Flood Management Program and Disaster management program. The Flood Management Program consists of a Drainage / Sewerage Development Program, a development, management and conservation program for rivers, lakes and other water resources, a Flood Control Program and a drainage / rehabilitation channel / drainage program with the person in charge of the Office of Public Works and Spatial Planning, with details on Table 3:

Table 3

Strategies Regarding Flood Management (RPJMD 2016-2021)

\begin{tabular}{|l|l|l|l|l|}
\hline No. & \multicolumn{1}{|c|}{ Objectives } & \multicolumn{1}{|c|}{$\begin{array}{c}\text { Performance } \\
\text { Indicators } \\
\text { (outcome) }\end{array}$} & $\begin{array}{c}\text { Performance } \\
\text { Achievement in 2016 } \\
\text { (baseline)/Targets } \\
\mathbf{2 0 2 1}\end{array}$ & \multicolumn{1}{|c|}{$\begin{array}{c}\text { SKPD in } \\
\text { Charge }\end{array}$} \\
\hline 1. & $\begin{array}{l}\text { Increased flood } \\
\text { prevention }\end{array}$ & $\begin{array}{l}\text { Flood inundation } \\
\text { area }\end{array}$ & $1,3 / 1,55$ & $\begin{array}{l}\text { BPBD, } \\
\text { DPUPR, DLH }\end{array}$ \\
\hline
\end{tabular}

Source : (RPJMD Kabupaten Bandung 2016 - 2021, 2016)

Quality of Strategic Plan for 2016 - 2021 Goals and targets in the RPJMD relating to flood prevention efforts are results oriented but the objectives and indicators contained in the RPJMD and do not fully meet the criteria of good indicators that can be measured objectively, relevant to the conditions to be measured, although its already illustrates the results that are will be achieved however not enough to describe the LG's performance. This is very influential on the results of evaluating the quality of performance targets, because programs / activities as a way to achieve the targets and the quality of alignment with the planning documents above.

While in the main indicators (IKU) (P. K. Bandung, 2017a) and performance agreement (B. Bandung, 2017) of Bandung Regency RPJMD in 2016 - 2021, third mission is realizating infrastructure development that is integrated with spatial areas with due regard to disaster aspects. The aim is to increase the availability of quality basic infrastructure that is resilient to disasters and to realize harmony of development with regional spatial planning. The objectives were changed to "Increased efforts to deal with flood-stricken communities with two performances indicators: the percentage of polders / retention ponds (5\%) and the percentage of drainage treatment at the Regional and Urban scale (10,02\%). The formulation of objectives in KPI and PK is still a process and not outcome oriented and the indicator still output while the 
formulation of target performance indicators how to calculate them was explained in the 2017 Performance Accountability report (Pemerintah Kabupaten Bandung Tahun 2017, 2018). Based on the 2016 and 2017 Performance Accountability Report, the performance of this target is still not effective due to the unrealized pool retention ( $P$. K. Bandung, 2017b), (B. Bandung, 2017).

4. Reviewing selected interventions and determine operational plans that link strategic goals and objectives with operational goals and objectives, usually carried out by the unit underneath, regarding what and how and who will carry out or be responsible.

Based on data obtained from the RPJMD Flood Mitigation Program for the period of 2016 - 2021 carried out by three OPDs, but after the researchers examined the documents, the flood control OPD program only exists at the Public Works Department with the following details:

Table 4

Programs Regarding Flood Management in Bandung Regency (RPJMD 2016-2021)

\begin{tabular}{|l|l|}
\hline 3.1.6.1 & Program Penanggulangan Banjir \\
\hline 1.3.1 & DINAS PEKERJAAN UMUM DAN PENATAAN RUANG \\
\hline 3.1.4.16 & Program for the construction of drainage channels / culverts \\
\hline 3.1.4.26 & $\begin{array}{l}\text { Development, management and conversion program for rivers, lakes and } \\
\text { other water resources }\end{array}$ \\
\hline 3.1.4.28 & Flood control program \\
\hline 3.1.4.33 & Drainage / Culverts Rehabilitation / Maintenance Program \\
\hline 1.5.2 & BADAN PENANGGULANGAN BENCANA DAERAH \\
\hline 3.2.1.24 & Flood Control Program \\
\hline
\end{tabular}

Source: RPJMD 2016 - 2021

As for the program inputs mean the resources that are invested in the program initiative can be divided into money, people, and time. Financial assistance comes primarily from the budget and local budget revenues (APBD) or through grant funding. People include regency leaders, district leaders, heads of organization, officials who making commitments on flood-related programs, disaster management teams, school administrators, community partners, residents living in disaster areas, farmers, companies/factories located around rivers, media representatives, first responders, experts, and evaluators. The time and resources that people put into the program include programming, coordination between Regional Organization (OPD), meetings and training, and instructional supplies.

Some things that must be done before intervening include determining the specific objectives and assessment indicators of the intervention, by whom, how and where the intervention is carried out, who is the recipient of the intervention and the cost of the 
intervention. In DLM, the terms output and effect are basically interpreted to mean the same thing that describes the results of an intervention. All effects of interventions must be documented including the relationship of effects to the objectives of the intervention including how and when effects are measured (indicators used) and all other effects (positive and negative including how and when they are assessed.

While outcomes are changes or results of a particular intervention that is expected to be achieved, the results of interventions relative to the objectives of the intervention (William, 2013 and Zint 2013 as cited in Birnbaum et al. 2016) While the impact in The Business Dictionary (2011) and Thomson (1995) as cited by Birnbaum et al, (2016) is defined as social, economic, civil and environmental consequences of a program / intervention, long-term changes that occur in a community, organization, community, or environment as a result of effects (interventions). Impact outcomes may include increased functional knowledge and skills, improved village/district safety, faster response time to emergency drills, and changed attitudes and beliefs about emergency management especially in flood disaster.

Table 5

Logic Model related to the Flood Mitigation Program (RPJMD 2016-2021) of Bandung Regency

\begin{tabular}{|c|c|c|c|c|c|}
\hline \multicolumn{3}{|r|}{ Intervention } & Process & Output & $\begin{array}{c}\text { Outcome } \\
\text { (expected) }\end{array}$ \\
\hline \multicolumn{6}{|c|}{ Tahun 2016} \\
\hline \multicolumn{6}{|c|}{ Dinas Pekerjaan Umum } \\
\hline \multirow[t]{2}{*}{1} & \multicolumn{2}{|c|}{$\begin{array}{l}\text { Construction of drainage } \\
\text { channels / culverts Program }\end{array}$} & & & \\
\hline & $\mathrm{a}$ & $\begin{array}{l}\text { Planning for the } \\
\text { construction of } \\
\text { drainage channels / } \\
\text { culverts }\end{array}$ & $\begin{array}{l}\text { Availability of } \\
\text { development } \\
\text { planning } \\
\text { documents } \\
\text { draenase / culverts } \\
\text { (11 Documents) }\end{array}$ & $\begin{array}{l}\text { availability of } \\
\text { Draenase / Culverts } \\
\text { Development } \\
\text { Planning } \\
\text { Documents }(100 \%)\end{array}$ & $\begin{array}{l}\text { decreasing } \\
\text { inundation } \\
\text { area }\end{array}$ \\
\hline & $\mathrm{b}$ & $\begin{array}{l}\text { Construction of } \\
\text { drainage channels / } \\
\text { culverts }\end{array}$ & $\begin{array}{l}\text { Construction of } \\
\text { draenase / culvert } \\
\text { channel (163 } \\
\text { locations) }\end{array}$ & $\begin{array}{l}\text { draenase / culvert } \\
\text { drainage } \\
\text { construction }(100 \%)\end{array}$ & $\begin{array}{l}\text { decreasing } \\
\text { inundation } \\
\text { area }\end{array}$ \\
\hline & c & $\begin{array}{l}\text { Drainage Development } \\
\text { (Governor's Support) }\end{array}$ & $\begin{array}{l}\text { Construction of } \\
\text { draenase and } \\
\text { culvert channels } \\
(2,311 \mathrm{~km})\end{array}$ & $\begin{array}{l}\text { draenase / culvert } \\
\text { channel } \\
\text { construction } \\
(42.02 \%)\end{array}$ & $\begin{array}{l}\text { decreasing } \\
\text { inundation } \\
\text { area }\end{array}$ \\
\hline \multicolumn{3}{|c|}{ Tahun 2017} & & & \\
\hline
\end{tabular}




\begin{tabular}{|c|c|c|c|c|c|}
\hline 1 & \multicolumn{2}{|c|}{$\begin{array}{l}\text { Construction of drainage } \\
\text { channels / culverts Program }\end{array}$} & \multirow[b]{2}{*}{$\begin{array}{l}\text { Availability of } \\
\text { development } \\
\text { planning } \\
\text { documents } \\
\text { draenase / culverts } \\
\text { (15 Dokumen) }\end{array}$} & \multirow[b]{2}{*}{$\begin{array}{l}\text { Draenase / Culverts } \\
\text { Development } \\
\text { Planning } \\
\text { Documents (100\%) }\end{array}$} & \multirow[b]{2}{*}{$\begin{array}{l}\text { decreasing } \\
\text { inundation } \\
\text { area }\end{array}$} \\
\hline & $\mathrm{a}$ & $\begin{array}{l}\text { Planning for the } \\
\text { construction of } \\
\text { drainage channels / } \\
\text { culverts }\end{array}$ & & & \\
\hline & $\mathrm{b}$ & $\begin{array}{l}\text { Construction of } \\
\text { drainage channels / } \\
\text { culverts }\end{array}$ & $\begin{array}{l}\text { Construction of } \\
\text { draenase / culvert } \\
\text { channel ( } 514 \\
\text { Location) }\end{array}$ & $\begin{array}{l}\text { draenase / culvert } \\
\text { drainage } \\
\text { construction }(100 \%)\end{array}$ & $\begin{array}{l}\text { decreasing } \\
\text { inundation } \\
\text { area }\end{array}$ \\
\hline & c & $\begin{array}{l}\text { Drainage Development } \\
\text { (Governor's Support) }\end{array}$ & $\begin{array}{l}\text { Construction of } \\
\text { draenase and } \\
\text { culvert channels } \\
\text { (158 Kegiatan) }\end{array}$ & $\begin{array}{l}\text { draenase / culvert } \\
\text { drainage } \\
\text { construction }(100 \%)\end{array}$ & $\begin{array}{l}\text { decreasing } \\
\text { inundation } \\
\text { area }\end{array}$ \\
\hline \multirow[t]{2}{*}{2} & \multicolumn{2}{|c|}{$\begin{array}{l}\text { Development, management } \\
\text { and conversion program for } \\
\text { rivers, lakes and other water } \\
\text { resources }\end{array}$} & & & \\
\hline & a & $\begin{array}{l}\text { Master plan for water } \\
\text { resources }\end{array}$ & $\begin{array}{l}\text { Availability of } \\
\text { Ciwidey Sub- } \\
\text { watershed DED } \\
\text { Documents (1 } \\
\text { Document) }\end{array}$ & $\begin{array}{l}\text { Directional } \\
\text { planning and } \\
\text { implementation of } \\
\text { river and drainage } \\
\text { channel } \\
\text { conservation (1 } \\
\text { dump planning } \\
\text { channel } \\
\text { (Rancamalang) }\end{array}$ & $\begin{array}{l}\text { increased } \\
\text { comprehensive } \\
\text { planning of } \\
\text { water resource } \\
\text { management }\end{array}$ \\
\hline \multirow[t]{4}{*}{3} & \multicolumn{2}{|c|}{ Flood Control Program } & & & \\
\hline & a & $\begin{array}{l}\text { Rehabilitation and } \\
\text { maintenance of river } \\
\text { banks and } \\
\text { embankments }\end{array}$ & $\begin{array}{l}\text { Implementation of } \\
\text { river and } \\
\text { embankment } \\
\text { rehabilitation (56 } \\
\text { rivers / drainage } \\
\text { canals) }\end{array}$ & $\begin{array}{l}\text { Reduced water } \\
\text { damage (56 } \\
\text { locations) }\end{array}$ & $\begin{array}{l}\text { Reduced water } \\
\text { damage }\end{array}$ \\
\hline & $\mathrm{b}$ & $\begin{array}{l}\text { Increasing community } \\
\text { participation in flood } \\
\text { management }\end{array}$ & $\begin{array}{l}\text { Flooding material } \\
\text { available } \\
\text { (Temporary } \\
\text { Countermeasures) } \\
\text { (4 Sub Das) }\end{array}$ & $\begin{array}{l}\text { Increased } \\
\text { community } \\
\text { participation in } \\
\text { flood management } \\
\text { (4 Sub Das) }\end{array}$ & $\begin{array}{l}\text { Increased } \\
\text { community } \\
\text { participation in } \\
\text { flood } \\
\text { management (4 } \\
\text { Sub Das) } \\
\end{array}$ \\
\hline & c & $\begin{array}{l}\text { Improved river } \\
\text { cleaning and dredging }\end{array}$ & $\begin{array}{l}\text { Implementation of } \\
\text { River O \& P / Sewer } \\
\text { (14 locations) }\end{array}$ & $\begin{array}{l}\text { Increased } \\
\text { optimization of } \\
\text { drainage network } \\
\text { functions (14 rivers } \\
\text { / drainage canals) }\end{array}$ & $\begin{array}{l}\text { decreasing } \\
\text { inundation } \\
\text { area }\end{array}$ \\
\hline
\end{tabular}




\begin{tabular}{|c|c|c|c|c|c|}
\hline & d & $\begin{array}{l}\text { Retention Pool } \\
\text { Construction }\end{array}$ & $\begin{array}{l}\text { Implementation of } \\
\text { land acquisition } \\
\text { preparation for the } \\
\text { construction of } \\
\text { polders for flood } \\
\text { control (Appraisel } \\
\text { and Site } \\
\text { Determination) (1 } \\
\text { activity) }\end{array}$ & $\begin{array}{l}\text { Availability of } \\
\text { reference for land } \\
\text { acquisition for flood } \\
\text { control poder } \\
\text { manufacturing ( } 1 \\
\text { Activity) }\end{array}$ & $\begin{array}{l}\text { decreasing } \\
\text { inundation } \\
\text { area }\end{array}$ \\
\hline & $\mathrm{e}$ & $\begin{array}{l}\text { River / Sewer } \\
\text { Normalization }\end{array}$ & $\begin{array}{l}\text { Implementation of } \\
\text { river / drainage } \\
\text { normalization ( } 8 \\
\text { River / Sewer) }\end{array}$ & $\begin{array}{l}\text { Reduced Water } \\
\text { Damage ( } 8 \\
\text { Locations) }\end{array}$ & $\begin{array}{l}\text { decreasing } \\
\text { inundation } \\
\text { area }\end{array}$ \\
\hline \multicolumn{6}{|c|}{ Tahun 2018} \\
\hline \multirow[t]{4}{*}{1} & \multicolumn{2}{|c|}{$\begin{array}{l}\text { Construction of drainage } \\
\text { channels / culverts Program }\end{array}$} & & & \\
\hline & $\mathrm{a}$ & $\begin{array}{l}\text { Planning for the } \\
\text { construction of } \\
\text { drainage channels / } \\
\text { culverts }\end{array}$ & $\begin{array}{l}\text { Number of } \\
\text { Drainage / Culverts } \\
\text { Development } \\
\text { Planning } \\
\text { Documents (38 } \\
\text { Documents) } \\
\end{array}$ & $\begin{array}{l}\text { Percentage of } \\
\text { availability of } \\
\text { Draenase / Culverts } \\
\text { Development } \\
\text { Planning } \\
\text { Documents }(100 \%) \\
\end{array}$ & $\begin{array}{l}\text { decreasing } \\
\text { inundation } \\
\text { area }\end{array}$ \\
\hline & $\mathrm{b}$ & $\begin{array}{l}\text { Construction of } \\
\text { drainage channels / } \\
\text { culverts }\end{array}$ & $\begin{array}{l}\text { Length of Drainage } \\
\text { Drains / Culverts } \\
\text { Built (72451 meters) }\end{array}$ & $\begin{array}{l}\text { Percentage of } \\
\text { Draenase / Culvert } \\
\text { Channel } \\
\text { Construction } \\
(100 \%)\end{array}$ & $\begin{array}{l}\text { decreasing } \\
\text { inundation } \\
\text { area }\end{array}$ \\
\hline & c & $\begin{array}{l}\text { Drainage Development } \\
\text { (Governor's Support) }\end{array}$ & $\begin{array}{l}\text { Number of } \\
\text { Monitoring and } \\
\text { Evaluation } \\
\text { Documents (4 } \\
\text { Documents) } \\
\end{array}$ & $\begin{array}{l}\text { Percentage of } \\
\text { Monitoring and } \\
\text { Evaluation } \\
\text { Documents } \\
\text { available }(100 \%) \\
\end{array}$ & $\begin{array}{l}\text { decreasing } \\
\text { inundation } \\
\text { area }\end{array}$ \\
\hline \multirow[t]{2}{*}{2} & \multicolumn{2}{|c|}{$\begin{array}{l}\text { Development, management } \\
\text { and conversion program for } \\
\text { rivers, lakes and other water } \\
\text { resources }\end{array}$} & & & \\
\hline & $\mathrm{a}$ & $\begin{array}{l}\text { Master plan for water } \\
\text { resources }\end{array}$ & $\begin{array}{l}\text { Availability of } \\
\text { Master Plan } \\
\text { Documents (32 } \\
\text { Documents) }\end{array}$ & $\begin{array}{l}\text { Percentage of } \\
\text { availability of } \\
\text { drainage planning } \\
\text { documents }(100 \%)\end{array}$ & $\begin{array}{l}\text { increased } \\
\text { comprehensive } \\
\text { planning of } \\
\text { water resource } \\
\text { management } \\
\end{array}$ \\
\hline \multirow[t]{3}{*}{3} & \multicolumn{2}{|c|}{ Flood Control Program } & & & \\
\hline & $\mathrm{a}$ & $\begin{array}{l}\text { Rehabilitation and } \\
\text { maintenance of river } \\
\text { banks and } \\
\text { embankments }\end{array}$ & $\begin{array}{l}\text { Number of river } \\
\text { banks and } \\
\text { embankments being } \\
\text { rehabilitated (4 Sub } \\
\text { Das) }\end{array}$ & $\begin{array}{l}\text { Reduced water } \\
\text { damage }(100 \%))\end{array}$ & $\begin{array}{l}\text { Reduced water } \\
\text { damage }\end{array}$ \\
\hline & $\mathrm{b}$ & $\begin{array}{l}\text { Increasing community } \\
\text { participation in flood } \\
\text { management }\end{array}$ & $\begin{array}{l}\text { Amount of Material } \\
\text { / Materials ( } 5 \text { Types) }\end{array}$ & $\begin{array}{l}\text { Percentage of } \\
\text { material fulfillment } \\
(100 \%)\end{array}$ & $\begin{array}{l}\text { Increased } \\
\text { community } \\
\text { participation in }\end{array}$ \\
\hline
\end{tabular}




\begin{tabular}{|c|c|c|c|c|}
\hline & & & & $\begin{array}{l}\text { flood } \\
\text { management }\end{array}$ \\
\hline c & $\begin{array}{l}\text { Improved river } \\
\text { cleaning and dredging }\end{array}$ & $\begin{array}{l}\text { Number of } \\
\text { Cleaning and } \\
\text { Dredging of River / } \\
\text { Sewer Channels (41 } \\
\text { Locations) }\end{array}$ & $\begin{array}{l}\text { Percentage of } \\
\text { Number of } \\
\text { Cleaning and } \\
\text { Dredging of River } \\
\text { Channels / Drains } \\
(100 \%)\end{array}$ & $\begin{array}{l}\text { decreasing } \\
\text { inundation } \\
\text { water due to } \\
\text { flooding }\end{array}$ \\
\hline $\mathrm{d}$ & $\begin{array}{l}\text { Land acquisition for } \\
\text { flood control }\end{array}$ & $\begin{array}{l}\text { Amount of Land } \\
\text { Acquisition for Lake } \\
\text { and Flood Control } \\
\text { Folder (7 Locations) }\end{array}$ & $\begin{array}{l}\text { Percentage of total } \\
\text { land acquisition for } \\
\text { lakes and flood } \\
\text { control folders } \\
(100 \%)\end{array}$ & $\begin{array}{l}\text { decreasing } \\
\text { inundation } \\
\text { water due to } \\
\text { flooding }\end{array}$ \\
\hline
\end{tabular}

\begin{tabular}{|l|l|l|l|l|l|}
\hline \multicolumn{2}{|l|}{ BPBD } & \multicolumn{2}{l|}{} & & \\
\hline Tahun 2018 & & $\begin{array}{l}\text { Community } \\
\text { empowerment in } \\
\text { facing disasters }\end{array}$ & $\begin{array}{l}\text { Implementation of } \\
\text { DRR Socialization }\end{array}$ & $\begin{array}{l}\text { The formation of } \\
\text { the DRR Forum }\end{array}$ & $\begin{array}{l}\text { improved } \\
\text { coordination of } \\
\text { disaster } \\
\text { management } \\
\text { between actors }\end{array}$ \\
\hline & b & $\begin{array}{l}\text { The socialization of } \\
\text { gender mainstreaming } \\
\text { in the field of disaster } \\
\text { management }\end{array}$ & $\begin{array}{l}\text { The } \\
\text { implementation of } \\
\text { gender } \\
\text { mainstreaming } \\
\text { socialization in the } \\
\text { field of disaster } \\
\text { management }\end{array}$ & $\begin{array}{l}\text { Dissemination of PB } \\
\text { Gender } \\
\text { Mainstreaming } \\
\text { involvement of } \\
\text { women in } \\
\text { disaster } \\
\text { planning and } \\
\text { management }\end{array}$ \\
\hline c & $\begin{array}{l}\text { Disaster risk map } \\
\text { making (PRB) }\end{array}$ & $\begin{array}{l}\text { Implementation of } \\
\text { the making of } \\
\text { disaster risk maps } \\
\text { (DRR) }\end{array}$ & $\begin{array}{l}\text { Availability of } \\
\text { disaster risk map } \\
\text { (PRB) }\end{array}$ & $\begin{array}{l}\text { mitigate the } \\
\text { threat of } \\
\text { disaster }\end{array}$ \\
\hline d & $\begin{array}{l}\text { Preparation of disaster } \\
\text { risk assessment } \\
\text { documents }\end{array}$ & $\begin{array}{l}\text { The } \\
\text { implementation of } \\
\text { Disaster Risk } \\
\text { Assessment } \\
\text { Document } \\
\text { Arrangement }\end{array}$ & $\begin{array}{l}\text { The availability of } \\
\text { Disaster Risk } \\
\text { Assessment } \\
\text { Documents }\end{array}$ & $\begin{array}{l}\text { increased } \\
\text { public } \\
\text { awareness of } \\
\text { disasters }\end{array}$ \\
\hline
\end{tabular}

Source: Badan Keuangan Daerah

Based on the matrix above, it appears that over the past three years, the focus of intervention from the Flood Management Program in Bandung Regency lies in the drainage development by the Bandung District Public Works Department, this is contrary to the findings (Hapsari \& Zenurianto, 2016)that the policy on flood 
prevention is still lacking. However, in 2018, intervention to the community has been carried out through activities to increase community participation in flood management, community empowerment, socialization on gender mainstreaming in the field of disaster management. While to improve the quality of planning related to disasters, other activities undertaken are the preparation of a water resources master plan. In the past three years, there have not been any interventions for activities in the event of a disaster (response) and after a disaster (recovery), noting that flooding in these three regions still occurred within that time period. This is in line with (Deputi Bidang Sarana dan Prasarana, 2010) that local government policies are still limited to flood prevention.

However, because the DLM connects needs, goals and targets in strategic planning with interventions carried out, the achievement of Key Performance indicators over the past three years has been aimed to increase efforts to manage flooded communities with two indicators where percentages of retention ponds are only $0 \%$ in 2016 and $40 \%$ in 2017 signaled that some of its activities could not be carried out due to land acquisition that was owned by the community. While the indicator "Percentage of regional scale and city scale drainage treatment" unable to reach the target set given because there are parts of the road that do not yet have drainage. In addition, some of the existing drainage needs to be revitalized because it is not enough to accommodate water discharge, especially during the rainy season.

The change in target indicators from inundation area to two indicators that are still in the form of output indicates the asynchronization between the Strategic Plan and IKU / Performance Agreement. The target indicators at IKU are more directed towards structural improvement (drainage) while the needs indicated in the second phase imply that the interventions needed in tackling the flood problem in Bandung Regency are also related to the problem of garbage, industrial waste, community's dependence on assistance, conservation of the area protected forest, reforestation and the reluctance of people to move their homes. In other words, interventions can be carried out by DPOs other than the Public Works Office.

Although in the Bandung Regency Government Performance Report (P. K. Bandung, 2019) the achievement of strategic objectives in the 2016-2019 RPJMD received a very 
satisfying category, but in terms of the use of performance indicators namely inundation area, it has not shown good performance indicators. The area of inundation referred to is still categorized as a process and has not produced results because what is used as an indicator is the handling of flood inundation. The formulation of performance indicators that can reflect the increase in flood prevention is a decrease in the area of flood inundation at a certain point (Table 6)

Table 6

The Achievement of Flood Mitigation Performance Until 2018

\begin{tabular}{|c|c|c|c|c|c|c|c|c|}
\hline \multirow[b]{2}{*}{$\begin{array}{l}\text { Sasaran } \\
\text { Strategis }\end{array}$} & \multirow[b]{2}{*}{$\begin{array}{c}\text { Indikator } \\
\text { Kinerja }\end{array}$} & \multicolumn{2}{|c|}{ Realisasi } & \multicolumn{5}{|c|}{ Kinerja 2018} \\
\hline & & 2016 & 2017 & $\begin{array}{c}\text { Targ } \\
\text { et }\end{array}$ & $\begin{array}{c}\text { Realisas } \\
\text { i }\end{array}$ & $\begin{array}{c}\text { Capaia } \\
\text { n (\%) }\end{array}$ & $\begin{array}{l}\text { Keterc } \\
\text { apaian }\end{array}$ & $\begin{array}{c}\text { Kategori } \\
\text { Ketercapai } \\
\text { an Kinerja }\end{array}$ \\
\hline $\begin{array}{l}\text { Meningkatny } \\
\text { a } \\
\text { penanggulan } \\
\text { gan banjir }\end{array}$ & $\begin{array}{l}\text { Luas } \\
\text { genangan } \\
\text { (penangana } \\
\mathrm{n} \text { ) }\end{array}$ & 1,30 & 1,35 & 1,4 & 1,42 & $\begin{array}{c}104,43 \\
\%\end{array}$ & $\begin{array}{l}\text { Tercap } \\
\text { ai }\end{array}$ & $\begin{array}{l}\text { Sangat } \\
\text { Memuaska } \\
\mathrm{n}\end{array}$ \\
\hline
\end{tabular}

Source: (P. K. Bandung, 2019)

5. Determine external factors. External factors include: the situation / environment in which the intervention was implemented; community culture, weather, terrain, security, and / or other interventions planned or underway in the area. External factors relating to the evaluation of risk reduction interventions include other interventions previously carried out to reduce the risk of an event from danger, and / or increase the absorption, buffering, and or capacity response of the community or system being studied.

The problem of flooding in the Upper Citarum Watershed does not only involve the Bandung Regency Government but the West Java Provincial Government and the Central Government which has programs aimed at and located in the Citarum River Basin area. One of them is the Integrated Citarum Water Resources Management Investment Program (ICWRMIP) which based on studies (Husein, Nurasa, Adiwisastra, \& Myrna, 2018) concluded that coordination between actors involved in the Citarum watershed area is still ineffective, there is still a sectoral ego to make the Citarum problem a unity of planning and management. Meanwhile according to (Arief, 2013) floods that occur in the upper reaches of the Citarum watershed are caused by changes in land use, where the forest area is turned into an agricultural area. 
In addition to the ICWRMIP Program (2008 - 2023) which aims to improve the upstream water catchment area until the availability of drinking water and quality improvement, since 1989, the government has launched various programs, one of which is the Clean River Program (Prokasih), one of which focuses on the watershed Citarum but not within the authority of the Bandung Regency Government. In 2001 there was the Citarum Bergetar Program by the Government of West Java Province whose main agenda was to improve policies, control pollution, conservation and empowerment which then continued with the Bestari Citarum Program in 2013 with the target that in 2018, Citarum river water could be drunk. Then in 2018 under the leadership of the Coordinating Ministry for Maritime Affairs the Citarum Harum Program was launched (Kumparan, 2018).

The community structure of the Dayeuh Kolot and Andir people is dominated by the middle class and is educated so that they have more social resilience when facing flood disasters than Bojongsoang villagers, who are partly classified as poor and geographically isolated. While NGOs provide the impact of community dependence on outside assistance (Muhamad et al., 2017)

6. In DLM input consists of resources used by interventions that have been carried out, including human resources, finance, opportunities for goods and services, environment and politics.

The budget for the Flood Prevention Program in Bandung District in the past ten years experienced a significant increase starting in 2016 as seen on Figure 3 compared to the budget in the previous five years. In 2012 the program budget amount for Rp 6.085.507.500,00 and to be three times higher in 2017. However, floods in the last year still occur in three districts of Bandung Regency (Liputan 6, 2019). 
Figure 3.

The Budget for Program Penanggulangan Banjir in Bandung Regency

(For The Year 2012 - 2021)

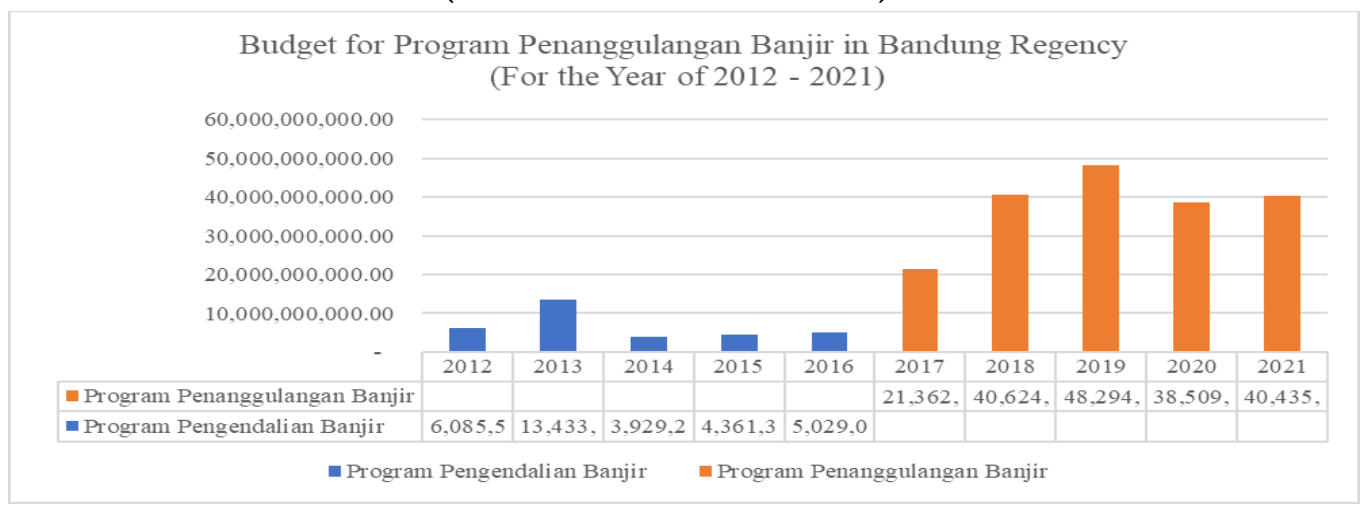

Source: Bandung Regency RPJMD 2010-2015 and 2016-2021

\section{Conclusion}

According to the analysis above, researchers have not been able to categorize the flood control program performance in Bandung Regency as an effective program. The performance of the flood disaster management program in 2016 - 2018 which was assessed from the achievement of the performance indicators in RPJMD and from key performance indicators and also from the result of logic model analysis. The ineffectiveness of the implementation of flood disaster management programs is especially because the absence of appropriateness of performance indicators in mid-term planning with key performance indicators and indicators in performance planning. In addition, the selection of performance indicators that do not describe the results and key performance indicators that do not reach the target because some activities cannot be carried out and activities that had been previously planned not implemented and did not achieve the expected goals. The Bandung Regency Government is expected to make improvements in the strategic planning for this program by involving the participation of the community and other stakeholders as well as preparing a master plan for flood mitigation, which contains flood prevention strategies at the stages of flood preparation, mitigation, response and recovery that is integrated between regional and cross-sectoral agents.

\section{References}

Aerts, J. C. J. H., Botzen, W. J. W., Emanuel, K., Lin, N., \& Moel, H. De. (2014). Evaluating Flood Resilience Strategies for Coastal Megacities. Science, 344, 473-475.

Akbar, M. S., \& Aldrich, D. P. (2015). Flood Damage and Victims' Perceptions About 
Political Leadership. Risk, Hazards $\mathcal{E}$ Crisis in Public Policy, 6(4), 329-343. https://doi.org/10.1002/rhc3.12089

Albrecht, F. (2017). Government Accountability and Natural Disasters: The Impact of Natural Hazard Events on Political Trust and Satisfaction With Governments in Europe. Risk, Hazards and Crisis in Public Policy, 8(4), 381-410. https://doi.org/10.1002/rhc3.12122

Arief, R. (2013). Banjir: Fakta dan Dampaknya, Serta Pengaruh dari Perubahan Guna Lahan Arief Rosyidie. Fakta Dan Dampaknya, Serta Penngaruh Dari Perubahan Guna Lahan Jurnal Perencanaan Wilayah Dan Kota, 24(3), 241-249. Retrieved from http://journals.itb.ac.id/index.php/jpwk/article/viewFile/4110/2196

Ayumahani, N. V., \& Ruslanjari, D. (2018). The Enhancement of Regional Disaster Management Agencies (BPBD) of Sumbawa Regency's Capability in Flash Flood Management Through Aid Assistance of Japan International Cooperation Agency (JICA). Policy \& Governance Review, 2(1), 56. https://doi.org/10.30589/pgr.v2i1.72

Bandung, B. (2017). Perjanjian Kinerja Bupati Bandung Tahun 2017 (pp. 1-6). pp. 1-6. Kabupaten Bandung.

Bandung, P. K. Pembentukan Organisasi badan Penanggulangan Bencana Kabupaten Bandung. , (2010).

Bandung, P. K. Pembagian Kewenangan, Tugas dan Fungsi Satuan Kerja Perangkat Daerah Dalam Penyelenggaraan Penanggulangan Bencana Di Kabupaten Bandung. , (2013).

Bandung, P. K. Perda No. 2 tahun 2013 tentang Penyelenggaraan Penanggulangan Bencana di Kabupaten Bandung. , (2013).

Bandung, P. K. (2015). Akuntabilitas Kinerja Tahun 2014 Pemerintah Kabupaten Bandung. Kabupaten Bandung.

Bandung, P. K. Indikator Kinerja Utama RPJMD Kabupaten Bandung Tahun 2016 -2021. , (2017).

Bandung, P. K. (2017b). Laporan Kinerja Instansi Pemerintah Kabupaten Bandung Tahun 2016. Retrieved from http://weekly.cnbnews.com/news/article.html?no=124000

Bandung, P. K. (2019). Laporan Kinerja Instansi Pemerintah Kabupaten Bandung Tahun 2018. Kabupaten Bandung.

BAPPEDA Kabupaten Bandung. Rencana Kerja Pembangunan Daerah Kabupaten Bandung Tahun 2016. , (2015). 
Birnbaum, M. L., Daily, E. K., O'Rourke, A. P., \& Kushner, J. (2016). Research and evaluations of the health aspects of disasters, Part VI: Interventional research and the disaster logic model. Prehospital and Disaster Medicine, 31(2), 181-194. https://doi.org/10.1017/S1049023X16000017

Blacksmith Institute. (2013). The Worlds Worst 2013: the Top Ten Toxic Threats Cleanup, Progress, and Ongoing Challenges Table. 19.

BNPB. (2016). Risiko bencana indonesia.

BPBD Kab Bandung. (2017). Profil BPBD Kabupaten Bandung (pp. 1-13). pp. 1-13. Kab Bandung.

BPKP. (2015). Pedoman teknis Peningkatan Kapabilitas Aparat Pengawasan Intern Pemerintah (p. 4). p. 4. Indonesia.

Burrel, B. C., Davar, K., Hughes, R., Technologies, H., Brunswick, N., Brunswick, N., \& Brunswick, N. (2007). A Review of Flood Management Considering the A Review of Flood Management Considering the Impacts of Climate Change. Water International, 32:3(December), 342-359. https://doi.org/10.1080/02508060708692215

Busson, T. L. (1983). the Need for Program and Performance Evaluation in Local Government. Policy Studies Journal, 12(2), 279-286. https://doi.org/10.1111/j.15410072.1983.tb00269.x

Col, J. M. (2007). Managing disasters: The role of local government. Public Administration Review, Vol. 67, pp. 114-124. https://doi.org/10.1111/j.1540-6210.2007.00820.x

Deputi Bidang Sarana dan Prasarana, Di. P. dan I. (2010). Kebijakan Penanggulangan Banjir di Indonesia. 1-17.

Deviana, A., Kridasantausa, I., \& Suryadi, Y. (2011). Kajian Pemodelan Spasial Banjir untuk Mendukung Kebijakan Sempadan Sungai dan Tata Ruang Wilayah (Studi Kasus Wilayah Pengembangan Baleendah). 1-21.

Dr George Argyrous, \& Rahman, S. (2016). A Monitoring and Evaluation Framework for Disaster Recovery Programs. Carlton: The Australia and New Zealand School of Government Ltd. Gerber, B. J., \& Robinson, S. E. (2009). Local Government Performance and the Challenges of Regional Preparedness for Disasters. Public Performance \& Management Review, 32(3), 345-371. https://doi.org/10.2753/pmr1530-9576320301

Hansson, K., Danielson, M., \& Ekenberg, L. (2008). A framework for evaluation of flood 
management strategies. Journal of Environmental Management, 86(3), 465-480. https://doi.org/10.1016/j.jenvman.2006.12.037

Hapsari, R. I., \& Zenurianto, M. (2016). View of Flood Disaster Management in Indonesia and the Key Solutions American Journal of Engineering Research ( AJER ). American Journal of Engineering Research, 5(3), 140-151.

Hatry, H. P. (2013). Sorting the Relationships Among Performance Measurement, Program Evaluation, and Performance Management. New D, 162(137), 19-32. https://doi.org/10.1002/ev

Henstra. (2010). Evaluating Local Government Emergency Management Programs: What Framework Should Public Managers Adopt? - Henstra - 2010 - Public Administration Review Wiley Online Library. (April), 236-246. Retrieved from http://onlinelibrary.wiley.com/doi/10.1111/j.1540-6210.2010.02130.x/full

Henstra, D. A. N. (2005). Management Policy: Moving Toward Paradigm Shift? Canadian Public Policy / Analyse de Politiques, 31(3), 303-318.

Hidayat, Y., Murtilaksono, K., Wahjunie, E. D., \& Panuju, D. R. (2013). The characteristics of river discharge of Citarum Hulu. Jurnal Ilmu Pertanian Indonesia (JIPI), 18(2), 109-114.

Husein, D., Nurasa, H., Adiwisastra, J., \& Myrna, R. (2018). Coordination on Integrated Citarum Water Resources Management Investment Program (ICRWMIP) in Bandung Regency. 141(ICOPOSDev 2017), 94-99. https://doi.org/10.2991/icoposdev-17.2018.20

Indonesia, P. UU No. 24 Tahun 2007 tentang Penanggulangan Bencana. , (2007).

Indonesia, P. UU No. 26 Tahun 2007 tentang Penataan Ruang. , (2007).

Indonesia, P. Pendanaan dan Pengelolaan Bantuan Bencana. , (2008).

Indonesia, P. Penyelenggaraan Penanggulangan Bencana. , (2008).

Indonesia, P. R. Peraturan Presiden Republik Indonesia No. 8 Tahun 2008 Tentang Badan Nasional Penanggulangan Bencana., (2008).

Istiani, R. S. (2016). Estimasi Nilai Kerugian Ekonomi dan Alternatif Kebijakan Pengurangan Dampak Banjir Sungai Citarum (Studi Kasus: Kelurahan Andir, Kecamatan Baleendah, Kabupaten Bandung) (Institute Pertanian Bogor). Retrieved from http://repository.ipb.ac.id/handle/123456789/85917

Jonker, J., \& Pennink, B. (2010). The essence of interaction design research. In Interactions (Vol. 17). https://doi.org/10.1145/1699775.1699786 
Kariuki, P., \& Reddy, P. (2017). Operationalising an effective monitoring and evaluation system for local government: Considerations for best practice. African Evaluation Journal, 5(2), 1-8. https://doi.org/10.4102/aej.v5i2.240

Kaushik, A. D., \& Sharma, V. K. (2012). Flood Management In India. LVIII NO.(January-March 2012), 119-136.

Khalid, M. S. Bin, \& Shafiai, S. B. (2014). Flood Disaster Management in Malaysia: An Evaluation of the Effectiveness Flood Delivery System. International Journal of Social Science and Humanity, 5(4), 398-402. https://doi.org/10.7763/ijssh.2015.v5.488

Kumparan. (2018). Gonta Ganti Jurus Pemerintah Untuk Citarum. Retrieved from 2018 website: https://kumparan.com/@kumparannews/gonta-ganti-jurus-pemerintah-untukcitarum

Larsson, A. (2008). A Framework for Evaluating Emergency Preparedness Plans and Response Strategies. IIASA Interim, (March), 33. Retrieved from http://miun.divaportal.org/smash/get/diva2:128376/FULLTEXT01.pdf

Lehtonen, M. (2005). OECD Environmental Performance Review Programme: $\begin{array}{lllll}\text { Accountability } & \text { (f)or } \quad \text { Learning? }\end{array}$ https://doi.org/10.1177/1356389005055536

Liaw, C. H., Tsai, Y. L., \& Cheng, M. S. (2006). Assessing flood mitigation alternatives in Shijr area in metropolitan Taipei. Journal of the American Water Resources Association, 42(2), 311-322. https://doi.org/10.1111/j.1752-1688.2006.tb03840.x

Lilik, K., Yunus, R., Muhammd, robi amir, \& Narwawi, P. (2011). Indeks Rawan Bencana Indonesia.

Liputan 6. (2019). https://www.liputan6.com/news/read/3934343/bpbd-kabupaten-bandungcatat-1500-rumah-terendam-

banjir?utm_expid=.9Z4i5ypGQeGiS7w9arwTvQ.0\&utm_referrer=.

Moe, T. L., Gehbauer, F., Senitz, S., \& Mueller, M. (2007). Balanced scorecard for natural disaster management projects. Disaster Prevention and Management: An International Journal, 16(5), 785-806. https://doi.org/10.1108/09653560710837073

Moe, T. L., \& Pathranarakul, P. (2006). An integrated approach to natural disaster management: Public project management and its critical success factors. Disaster Prevention and Management: An International Journal, 15(3), 396-413. 
https://doi.org/10.1108/09653560610669882

Muhamad, R. A. T., Sekarningrum, B., \& Yusar. (2017). Modal Sosial Dalam Penanggulangan Bencana Banjir (Kasus di Kabupaten Bandung, Jawa Barat). Jurnal Pemikiran Dan Penelitian Sosiologi, 1(2), 101-114.

Nicholls, K., \& Picou, J. S. (2013). The impact of hurricane katrina on trust in government. Social Science Quarterly, 94(2), 344-361. https://doi.org/10.1111/j.1540-6237.2012.00932.x

Pemerintah Kabupaten Bandung. Rencana Pembangunan Jangka Menengah Daerah (RPJMD) Kabupaten Bandung Tahun 2010-2015. , Pub. L. No. Perda No. 11 Tahun 2011, 1 (2011).

Pemerintah Kabupaten Bandung Tahun 2017. (2018). Laporan Kinerja Instansi Pemerintah (LKIP). Kab Bandung.

Poland, O. F. (1974). Program Evaluation and Administrative Theory Author ( s ): Orville F . Poland. Public Administration Review, 34(4), 333-338.

Ritchie, L. A., \& MacDonald, W. (2010). Enhancing Disaster and Emergency Preparedness, Response, and Recovery Through Evaluation. In New Directions for Evaluation (Vol. 162, pp. 1-7). https://doi.org/10.1002/ev

RPJMD Kabupaten Bandung 2016 - 2021. , (2016).

Sari, Z. (2017). Evaluasi Efektifitas Implementasi Program Penanggulangan Bencana Banjir Kabupaten Aceh Barat. C001-C004. https://doi.org/10.32315/ti.6.c001

Stame, N. (2006). Governance, Democracy and Evaluation. Evaluation, 12(1), 7-16. https://doi.org/10.1177/1356389006064173

Sutardi, D. (n.d.). Action Report toward Flood Disasters Reduction Indonesian Case Dr . Sutardi Action Report towards Flood Disaster Reduction Indonesian Case. In Indonesia Water Partnership. $\quad$ Retrieved from http://www.internationalfloodnetwork.org/AR2006/AR06Sutardi.pdf

Twigg, J. (2007). Evaluating Disaster Risk Reduction Intitiatives. In Tools for Mainstreaming Disaster Risk Reduction (pp. 1-14). Geneva: ProVention Consortium Secretariat.

Ulum, M. C., \& Chaijaroenwatana, B. (2013). Governance and Capacity Building of Handling the Flood Issue in Bojonegoro Municipality, Indonesia. Jurnal Administrasi Politik ,Kamphunnat, Manajemen Komunitas, Tahun 3, E(September 2012), 18-34.

Yin, R. K. (2015). Case study research design and methods (Fifth Edit). Sage Publication.

Zantal-Wiener, K., \& Horwood, T. J. (2010). Logic Modeling as a Tool to Prepare to Evaluate 
Disaster and Emergency Preparedness, Response, and Recovery in Schools. In Enhancing disaster and emergency preparedness, response, and recovery through evaluation (Vol. 126, pp. 51-64). https://doi.org/10.1002/ev 